former criticises the statistics of the Munich clinic, on the ground that there is such a wide discrepancy between these and the statistics of other operators-viz., freedom from recurrence in 64.5 per cent. of the cases of total extirpation of the cancerous uterus after the lapse of two years-and, that of the twenty-six patients reported as perfectly well, fifteen had reported only in writing. In reply the other gentlemen deny the allegation, and explain their unusually favorable results by the fact that in a considerable number of the cases the disease was limited to the portio, and that it is their practice to excise the tissues beyond the actual limits of the disease.

\title{
The Effect of Influenza upon Menstruation.
}

MrJnLIEFF (Nederl. Tijdskr.v. Geneeskunde; Centralblatt fïr Gynäkologie) noted that in women who were menstruating during an attack of influenza the flow was more profuse and prolonged. In a case of amenorrhca the flow reappeared after an absence of four months; in another it appeared for the first time during the attack. No special treatment was indicated. The increased flow must be explained as due either to an acute endometritis, or to the presence in the blood of pathogenic microörganisms, introduced through the respiratory tract, which give rise to certain vasomotor disturbances that may lead to hæmorrhages in other organs beside the uterus. It is possible that the microbes may generate ptomaines which exert a direct irritant action upon the vasomotor system.

\section{URETHRITIS AND ENDOMETRITIS.}

Vedeler (Norsk Mag. for Lägevid.; Centralblatt für Gynäkologie) calls attention to the relative frequency of virulent urethritis, and its influence upon accompanying pelvic affections. In 148 patients who were carefully examined with especial reference to this point, 1.5 per cent. had urethritis, 72 per cent. specific endometritis; in 32 per cent. there was disease of the adnexa, the latter almost never being present unless there was accompanying specific vaginitis. The latter he treats with astringent injections and suppositories, elldometritis with applications of acetate of lead in glycerin.

\section{The Ultmate Results of Total Extirpation of the Caycerous UTERUS.}

TANNEN (Archiv für Gynäkologie, Band xxxvii., Heft 3) presents the statistics of the Breslau clinic from June, 1883, to November, 1889, including one hundred and three cases of vaginal hysterectomy; the mortality in the first sixty cases being 11.6 per cent., in the last forty-three cases 6.9 per cent. Two deaths in the first series were due to ligation of the ureter, two to sepsis, and one to iodoform poisoning; in the second series there was only one death from sepsis. 47.4 per cent. of the patients were free from recurrence at the end of three years, but several were reported as well six years after the operation. Since the disease recurred from four to six years afterward, the writer believes that the operation can hardly be regarded as promising a radical cure. He believes that when the disease reappears it is usually within the pelvis rather than in the cicatrix, and usually occurs within a year after 
the operation, the average being seven months. When there are infiltrations in the broad ligaments the best treatment is thorough cauterization, which certainly prolongs life.

\section{The Mechanical Treatment of Uterine Tumors.}

Fredden berg (Frauenarat; Centralblatt für Gynäkologie, 1891) opposes the views of Kreissl and Carl Braun that neoplasms contra-indicate pelvic massage, and offers in evidence six cases of fibro-myoma of the uterus, which were diminished in size and the resulting symptoms relieved by the application of Thure Brandt's method, the rationale of which is the promotion of uterine contractions and the diminution of the blood-supply and pelvic congestion. This treatment is most effective when pursued during the menstrual period. No bad results have followed, and he thinks that it deserves a fair trial in the case of benignant neoplasms before adopting more radical measures.

\section{The Ultimate Results of Castration.}

Brodw ITz (Inaug. Dissert., Strassburg, 1890; Centralblatt für Gynäkologie, 1891), from a thorough study of this subject, arrives at the conclusion that in cases of general neurosis (hystero-epilepsy and epilepsy) the ovaries simply share in the central trouble, and hence castration cannot be expected to give permanent relief. Moreover, subsequent indurations and adhesions may increase the original irritation.

The ordinary sequelæ of castration are molimina, congestions, cardiac disturbances, flushing and vertigo, together with the diminution of sexual feelings in about two-thirds of the cases. Melancholy and forgetfulness are quite common, which may culminate in more pronounced psychoses. The writer's inference is that removal of the ovaries should be performed as infrequently as possible, in view of these serious after-effects.

\section{P A D I A T RIOS.}

UNDER THE CHARGE OF

JOHN M. KEATING, M.D., OF PHIYADELPHIA;
A. F. Corrier, M.D., OF NEW YORE,
W. A. EDWARDS, M D., of bas dIEgo, CaL.

\section{URTicaria in ChiLdRen.}

Cомву (Jahrb.f. Kinderheilk., xxxi. 1, 2) says that urticaria in children is accompanied by phenomena of a severe character, or may assume a chronic character and develop into prurigo. It is probably of toxic origin, occurs most frequently among badly nourished children living amid bad hygienic surroundings, and may be associated with dyspepsia and dilatation of the stomach. The hypothesis of a virus formed in the intestinal canal, taken up by the circulating blood and distributed over the skin would account for the gastic disturbances which so frequently accompany the disease. A predisposition to nervous diseases is also an influential factor, and all the disturbances 